\title{
EASTERN PACIFIC SPREADING RATE FLUCTUATION AND ITS RELATION TO PACIFIC AREA VOLCANIC EPISODES
}

\author{
DAVID K. REA and K.F. SCHEIDEGGER \\ Department of Atmospheric and Oceanic Science, University of Michigan, Ann Arbor, \\ Mich. 48109 (U.S.A.) \\ School of Oceanography, Oregon State University, Corvallis, Oreg. 97331 (U.S.A.)
}

(Received April 4, 1978; revised and accepted August 7, 1978)

\section{ABSTRACT}

Rea, D.K. and Scheidegger, K.F., 1979. Eastern Pacific spreading rate fluctuation and its relation to Pacific area volcanic episodes. J. Volcanol. Geotherm. Res., 5: 135-148.

Sea-floor spreading rates from four locations along the Nazca-Pacific plate boundary and one along the Juan de Fuca-Pacific plate boundary show variations over the past 2.4 m.y., with decreasing rates prior to the Jaramillo to Olduvai time interval $(0.92-1.73 \mathrm{~m} . \mathrm{y}$. ago) and increasing rates since then. Other Pacific area volcanic phenomena in mid-plate and convergent-boundary settings also show minima about $1.3-1.5 \mathrm{~m} . \mathrm{y}$. ago and a maximum at present and another maximum about $5 \mathrm{~m}$.y. ago: extrusion rates along the Hawaiian Ridge; volcanic episodes associated with calc-alkalic provinces of western Oregon and Central America; temporal variations in the $\mathrm{SiO}_{2}$ content of Aleutian ash layers; and the number of deep-sea ash layers. These phenomena may fluctuate in response to changing spreading rates. 'During times of more rapid spreading increased shear and melting along lithospheric boundaries may occasion increased volcanic activity, whereas during times of less rapid spreading volcanic activity may be less intense.

\section{INTRODUCTION}

Time-space studies of seismic activity have indicated that many of the earth's major seismic belts show roughly synchronous alternations between periods of greater and lesser earthquake activity (Mogi, 1974). In a more regional study, Berg and Sutton (1974) demonstrated a good correlation between cumulative strain release along the divergent and convergent boundaries of the Nazca plate. These and similar studies support the hypothesis of rigid plates and suggest that knowledge of the dynamic activity of one plate boundary may provide an insight into the dynamics of all of them. Periods of increased lithospheric accretion along a divergent plate boundary, for example, must, if plates are rigid, coincide with periods of increased subduction or collision along at least one convergent plate boundary (assuming constant earth radius). Several authors have suggested that episodes of volcanic activity 
associated with convergent boundary volcanism (Noble et al., 1974;

Scheidegger and Kulm, 1975; Kennett and Thunell, 1975) and mid-plate volcanism (Shaw, 1973; Vogt, 1972) may reflect changing spreading-subduction rates but detailed information on these relationships have not been available.

The most accurate record of horizontal motions at plate boundaries occurs at the world's spreading centers with the formation of linear magnetic anomalies. Such anomalies are most clearly displayed along the fast-spreading rises where the largest amounts of sea floor are formed during a given polarity inter. val and where there is the least amount of topographically induced noise in the geomagnetic signal. The East Pacific Rise (EPR) along the western edge of the Nazca plate is the most rapidly spreading portion of the oceanic ridge system having an average whole rate of accretion of about $160 \mathrm{~mm} / \mathrm{yr}$ (Table 1). Four regions along the Nazca-Pacific plate boundary have been surveyed in detail (Fig.1), and results of these surveys when taken together, provide an accurate picture of this plate boundary since the time of the Matuyama/Gauss magnetic reversal boundary about $2.4 \mathrm{~m}$.y. ago. This paper summarizes the EPR spreading rate information, compares it to variations in spreading rates occurring along the Juan de Fuca Ridge and then relates the observed synchronous variations in spreading rates along the eastern edge of the Pacific plate to mid-plate and convergent-boundary volcanism of the Pacific region.

TABLE 1

Sea-floor spreading rates $(\mathrm{mm} / \mathrm{yr})$ along the East Pacific Rise for anomaly-bound time intervals time scale of Klitgord (1974)

\begin{tabular}{llllll}
\hline Region & \multicolumn{2}{l}{ Time interval (m.y.) } & & & \\
\cline { 2 - 6 } & $0-0.70$ & $0.70-0.92$ & $0.92-1.73$ & $1.73-2.41$ & $2.41-3.78$ \\
\hline $6^{\circ} \mathrm{S}$ & 151.4 & 163.6 & 142.0 & & \\
$10.5^{\circ} \mathrm{S}$ & $157.8 \pm 1.8$ & $174.5 \pm 7.1$ & $145.6 \pm 3.2$ & & \\
$20^{\circ} \mathrm{S}$ & $162.3 \pm 4.5$ & $168.3 \pm 12.4$ & $155.9 \pm 5.5$ & $170.5 \pm 4.3$ & 175.8 \\
$31^{\circ} \mathrm{S}$ & $161.6 \pm 3.5$ & $(222.7 \pm 44.9)$ & $145.1 \pm 17.1$ & $166.7 \pm 10.4$ & 17.8 \\
Average/No. & $158.2 / 4$ & $168.3 / 3$ & $147.2 / 4$ & $168.6 / 2$ & $175.8 / 1$ \\
\hline
\end{tabular}

Note: Errors are one standard deviation. Rate in brackets is probably not valid, see text.

\section{Data}

Calculations of spreading rates depend on both accurate inter-anomaly distance measurements and an accurate geomagnetic time scale. The quality of distance measurements varies with the development of the magnetic anomalies in any given area. Of the information presented below, the least reliable figures are from the $6^{\circ} \mathrm{S}$ survey area. There, a northerly trending axis near the equator and the electrojet effect combine to produce low-amplitude anomalies and large, irregular diurnal variations (Rea, 1976a). Although only a few 


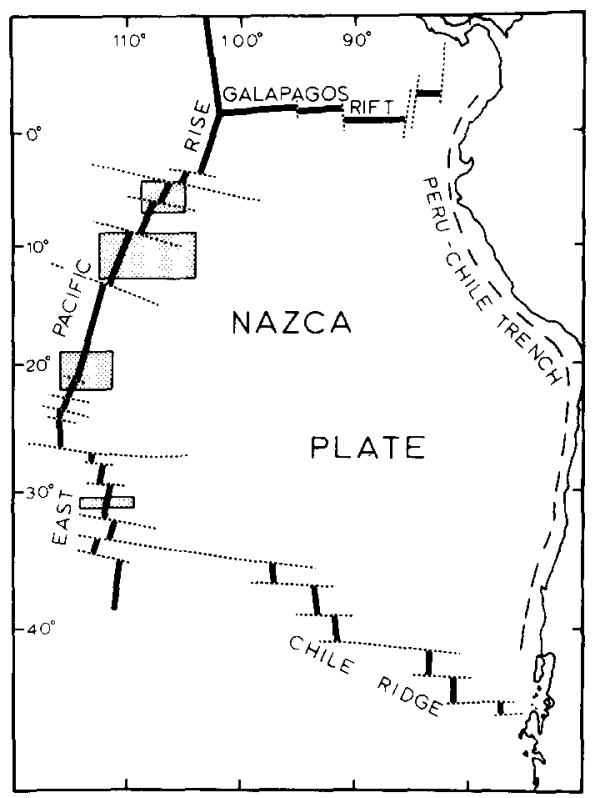

Fig.1. Index map of the Nazca plate. Shaded rectangles denote the four rise-crestsurvey areas.

anomalies can be identified with confidence at $6^{\circ} \mathrm{S}$, the data from this region which span the past $1.8 \mathrm{~m} . y$. are consistent with information from areas to the south (Tables 1 and 2 ). In the region between $9^{\circ}$ and $12^{\circ} \mathrm{S}$, which includes the $10.5^{\circ} \mathrm{S}$ survey area, 17 tracklines cross the axis and each line has several identifiable anomalies (Rea, 1975, 1976b). This data set also covers the past $1.8 \mathrm{~m} . \mathrm{y}$. The best set of magnetic-anomaly data comes from 19 tracklines crossing the EPR crestal region between $18.7^{\circ}$ and $21.5^{\circ} \mathrm{S}$ (Rea and Blakely, 1975; Rea, 1978). Anomalies here are clear and distinct and provide information on spreading rates since the time of the Matuyama/Gauss reversal boundary about 2.4 m.y. ago. A small rise-axis survey comprised of four tracklines forms the data set near $31^{\circ} \mathrm{S}$ (Rea, 1977). Anomalies here are usually unambiguous. About Jaramillo time (0.92 m.y. ago), however, the spreading axis

\section{TABLE 2}

Sea-floor spreading rates (in $\mathrm{mm} / \mathrm{yr}$ ) along the East Pacific Rise for anomaly-bound time intervals time scale of Tarling and Mitchell (1976)

\begin{tabular}{llllll}
\hline Region & \multicolumn{2}{l}{ Time interval (m.y.) } & & & \\
\cline { 2 - 5 } & $0-0.68$ & $0.68-0.92$ & $0.92-1.705$ & $1.705-2.41$ & $2.41-3.79$ \\
\hline $6^{\circ} \mathrm{S}$ & 155.9 & 150.0 & 146.5 & & \\
$10.5^{\circ} \mathrm{S}$ & $162.4 \pm 1.9$ & $160.0 \pm 6.5$ & $150.2 \pm 3.3$ & & \\
$20^{\circ} \mathrm{S}$ & $167.1 \pm 4.6$ & $154.3 \pm 11.4$ & $160.9 \pm 5.7$ & $164.6 \pm 4.1$ & \\
$31^{\circ} \mathrm{S}$ & $166.4 \pm 3.6$ & $(204.1 \pm 41.2)$ & $149.7 \pm 17.6$ & $160.8 \pm 10.0$ & 174.5 \\
Average/No. & $163.0 / 4$ & $154.8 / 3$ & $151.8 / 4$ & $162.6 / 2$ & $174.6 / 1$ \\
\hline
\end{tabular}

Note: Errors are one standard deviation. Rate in brackets is probably not valid, see text. 
was offset $10 \mathrm{~km}$ right laterally. This offset was healed by the time of the Brunhes/Matuyama reversal $(0.70 \mathrm{~m} . \mathrm{y}$. ago $)$ and as a result the spreading rates calculated for the interval $0.92-0.70 \mathrm{~m}$.y. ago are indicative of other than normal spreading processes (Rea, 1977). For this reason, we have not included these extreme values (Tables 1 and 2 ) in our considerations. The other values from this region seem sound and cover the interval back to the time of anomaly 3.1 about 3.8 m.y. ago.

Data on magnetic anomalies range from poor at $6^{\circ} \mathrm{S}$ to very good at $20^{\circ} \mathrm{S}$. The temporal coverage of the data is good back to $2.4 \mathrm{~m}$.y. ago, but only one trackline, from the $31^{\circ} \mathrm{S}$ area where anomalies are well-developed, crosses anomaly $2^{\prime}$ to $3.1-\mathrm{m}$.y. interval on both sides of the axis. There are no indications of any problems with this trackline and we have accepted the data from it as indicative of spreading rates during the $2.4-3.8-\mathrm{m}$. y. interval. Tables 1 and 2 summarize these data and show the total rate of sea-floor spreading for each anomaly-bound time interval. Errors shown are one standard deviation and reflect variations in interanomaly distances, not in time-scale accuracy.

Crustal accretion rates calculated from a set of measurements such as these also depend upon the ages assigned to the anomalies. Relatively small differences in age assignments of the magnetic reversals can produce important differences in apparent spreading rates. Data from the four EPR crestal survey areas have been combined with two different geomagnetic time scales in order to assess properly the variation due to the choice of time scales. The time scales chosen are those of: Klitgord (1974), with ages of 0.70 m.y. for the Brunhes/Matuyama reversal boundary, $0.92 \mathrm{~m}$.y. for the midpoint of the Jaramillo anomaly, 1.73 m.y for the midpoint of anomaly 2 , the Olduvai anomaly, $2.41 \mathrm{~m} . \mathrm{y}$. for the Matuyama/Gauss reversal boundary, and $3.78 \mathrm{~m} . \mathrm{y}$. for anomaly 3.1; and Tarling and Mitchell (1976), with ages for the same events of $0.68,0.92,1.705,2.41$, and $3.79 \mathrm{~m} . y$. Most of these assigned ages are similar and cause only minor changes in the apparent spreading rates. The only significant difference is in the age of the Brunhes/Matuyama reversal boundary, $0.70 \mathrm{~m} . \mathrm{y}$. vs. $0.68 \mathrm{~m} . \mathrm{y}$. This change alters the Brunhes/Matuyama to Jaramillo time span by about $9 \%$, a difference here of $14 \mathrm{~mm} / \mathrm{yr}$, and changes the spreading rates for the youngest interval since the Brunhes/Matuyama reversal by about $5 \mathrm{~mm} / \mathrm{yr}$.

\section{RESULTS AND DISCUSSION}

\section{Spatial variations in spreading rates}

A basic tenet of plate tectonics is that plates are rigid and that the linear spreading velocity at any point along a divergent boundary is a function of the angular distance from the pole of rotation and the angular rate of opening (Morgan, 1968). The angular rate of opening should be constant and the linear spreading rate increase towards the equator of plate rotation.

For most of the rotational poles determined for the Nazca-Pacific boundary, 
the $31^{\circ} \mathrm{S}$ survey area is within one degree of the rotational equator (Herron, 1972; Chase, 1972; Minster et al., 1974) and therefore should have the most rapid spreading rate of all regions for every interval. Tables 1 and 2 show that this apparently is not the case although differences between the $20^{\circ} \mathrm{S}$ and $31^{\circ}$ $\mathrm{S}$ rates are within the error ranges. If the overall spreading rates from 0 to $1.73 \mathrm{~m} . y$., the longest interval observed in all four regions, are calculated, results do show the north to south increase in spreading rate predicted by plate tectonic theory $\left(148.5 \mathrm{~mm} / \mathrm{yr}\right.$ at $6^{\circ} \mathrm{S}, 154.2$ at $10.5^{\circ} \mathrm{S}, 161.9 \mathrm{~mm} / \mathrm{yr}$ at $20^{\circ}$ $\mathrm{S}$, and $163.5 \mathrm{~mm} / \mathrm{yr}$ at $31^{\circ} \mathrm{S}$ ). Using these results and any of the several rotational poles published for the Nazca Pacific plate boundary, the angular velocity of opening for the time period $0-1.73 \mathrm{~m} . \mathrm{y}$. ago is determined to be $1.475^{\circ}$ \% m.y.

\section{Temporal variations in spreading rates}

Average spreading rates during the past 3.8 m.y. along the EPR are shown in Fig.2. Regardless of the time scale chosen, these plots show that starting at least 3.8 m.y. ago spreading rates steadily decreased until they reached a minimum value during the Jaramillo to Olduvai time period centered about 1.32
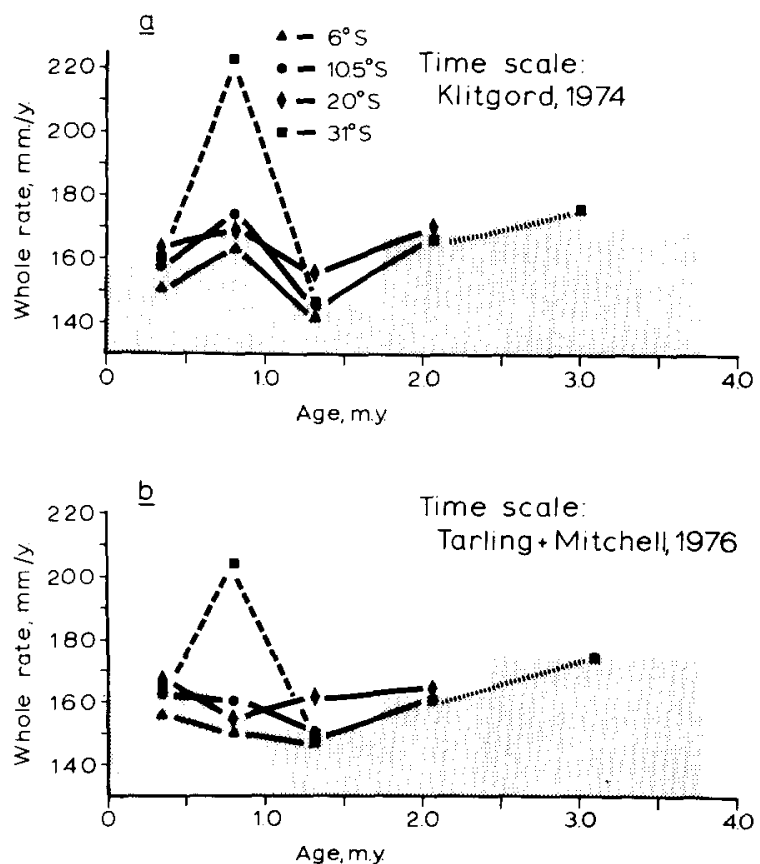

Fig. 2. East Pacific Rise spreading rates for each survey area (lines) and overall average from Tables 1 and 2 (shaded). (a) Time scale of Klitgord (1974). (b) Time scale of Tarling and Mitchell (1976). Dashed lines indicate uncertain rate from the $31^{\circ} \mathrm{S}$ area, dotted lines indicate information from one trackline only, see text. 
m.y. ago. Since that time rates have increased by about $7 \%$. It is possible that there was a brief spurt of rapid spreading during the Brunhes/Matuyama to Jaramillo time period centered at 0.81 m.y. ago (Fig.2a) but this effect may be an artifact of the Klitgord (1974) time scale. If the age of the Brunhes/ Matuyama reversal is set at $0.69 \mathrm{~m} . y$. (cf. Cox, 1969) then average spreading rates for the $0-0.69-\mathrm{m} . \mathrm{y}$. and $0.69-0.92-\mathrm{m} . \mathrm{y}$. intervals are $160.6 \mathrm{~mm} / \mathrm{yr}$ and $161.8 \mathrm{~mm} / \mathrm{yr}$, essentially the same.

The data presented above and in Tables 1 and 2 suggest that since $2.4 \mathrm{~m} . \mathrm{y}$. ago spreading rates in the southeast Pacific have first decreased and, more recently, increased again. In order to attempt a statistical validation of this observation we have performed $t$-tests on the spreading rate data from the $20^{\circ}$ $\mathrm{S}$ survey area where we have the most accurate and most numerous measurements. These tests compared the slower rates during the Jaramillo to Olduvai interval to the more rapid ones before and since. Results showed that, for the Klitgord (1974) time scale, the rate increase from $155.9 \pm 5.5 \mathrm{~mm} / \mathrm{yr}$ to the present one of $162.3 \pm 4.5 \mathrm{~mm} / \mathrm{yr}$ is significant at the $99 \%$ confidence level and the earlier rate reduction from $170.5 \pm 4.3 \mathrm{~mm} / \mathrm{yr}$ to $155.9 \pm 5.5 \mathrm{~mm} / \mathrm{yr}$ is significant at 99.9\%. When applied to the Tarling and Mitchell (1976) time scale the $t$-test shows that the recent spreading rate increase is significant at the $98 \%$ confidence level but that the prior rate decrease may not be significant ( $80 \%$ level). Using the recently published geomagnetic reversal time scale of LaBrecque et al. (1977), however, both the recent rate increase and prior decrease are statistically significant at the $95 \%$ and $99 \%$ levels, respectively. We may, therefore, conclude that the fluctuations in spreading rates during the past $2.4 \mathrm{~m} . \mathrm{y}$. that we find in the southeast Pacific are most likely a real phenomenon.

Other studies during the past few years have attempted to attribute volcanic episodes associated with various circum-Pacific and mid-Pacific volcanic phenomena to fluctuations in spreading rates. After first examining the spreading rate variations associated with another section of the Pacific plate divergent boundary, the Juan de Fuca Ridge, we will evaluate the proposed relationship between spreading rate variations and volcanic episodes.

\section{Variation of spreading rates on the Juan de Fuca Ridge}

The first place to look for rate changes in geological processes in the Pacific region is the other well-studied spreading center bordering the Pacific plate, the Juan de Fuca Ridge. Whole spreading rates for the same four time intervals back to anomaly 2 ' were determined from the least disturbed magnetic anomalies on either side of the ridge (lines 6-20 of the 1971 NOAA survey of that area). Results (Table 3 ) shows that the sea-floor spreading rates in the Juan de Fuca region have the same pattern as along the EPR, slowest during the Jaramillo to Olduvai interval and increasing by about $10 \%$ since then. As found for the EPR data, the recent spreading rate increase in the Juan de Fuca region is statistically significant for all three time scales, but the earlier rate reduction 
TABLE 3

Juan de Fuca Ridge spreading rates (in $\mathrm{mm} / \mathrm{yr}$ ) for anomaly-bound time intervals and for different time scales

\begin{tabular}{lllll}
\hline Time scale & Time interval & & & \\
\hline Tarling and & $(0-0.68$ m.y. & $(0.68-0.92$ m.y. & $(0.92-1.705$ m.y. & $(1.705-2.41)$ \\
Mitchell (1976) & $56.3 \pm 2.6$ & $53.6 \pm 2.5$ & $50.7 \pm 2.0$ & $50.6 \pm 2.5$ \\
Klitgord (1974) & $(0-0.70$ m.y.) & $(0.70-0.92$ m.y.) & $(0.92-1.73$ m.y.) & $(1.73-2.41)$ \\
& $54.7 \pm 2.6$ & $58.5 \pm 2.8$ & $49.1 \pm 1.9$ & $52.5 \pm 2.5$ \\
\hline
\end{tabular}

Note: Errors are one standard deviation.

is significant only for the time scales of Klitgord (1974) and of LaBrecque et al. (1977). As noted before, use of the Klitgord (1974) time scale incurs a brief spreading rate maximum during the Brunhes/Matuyama to Jaramillo interval (see Fig.4).

The information from the Juan de Fuca region is in general agreement with that from the Nazca-Pacific boundary and support the hypothesis that spreading rates all along the eastern edge of the Pacific plate have undergone synchronous variations during the past few million years.

\section{Temporal variations in Pacific area volcanism}

Changes in volcanic extrusion processes in the Pacific area have been studied by several authors. Kennett and Thunell (1975) investigated the global occurrence of ash layers through time in DSDP samples. They found that all regions showed a marked increase in volcanism since a minimum at about 2 m.y. ago with maxima at present and at about $5 \mathrm{~m}$.y. ago. Hays and Ninkovich (1970) suggest that volcanic activity in the northern Pacific began to increase markedly $1.8 \mathrm{~m} . \mathrm{y}$. ago, an observation confirmed by Stewart (1975) who has compiled similar data from three DSDP sites off the Kuril and Aleutian arcs. Stewart's (1975, fig.3) data show a discharge minimum about $1.5 \mathrm{~m} . \mathrm{y}$ ago with moderate activity prior to that time and high activity since. Hays and Ninkovich (1970), Kennett and Thunell (1975), and Kennett et al. (1977) link plate motions with volcanism patterns. Kennett and Thunell (1975) and Kennett et al. (1977) suggest that volcanic discharge rates may mimic and amplify changes in spreading rates because of the close coupling of activity along plate boundaries. In general, the northern Pacific ash-fall record seems to fit well with the spreading rate data, both of which show minima about 1.5 m.y. ago. Ninkovich and Donn (1976), however, suggest that the apparent increase in ash-fall frequency during the Pleistocene may be related to the convergence of the Pacific plate with the ash-producing volcanic arcs of the Eurasian and North American plates. This process certainly must be taken into account; however, it is our opinion that one would not expect a minimum in the ash fall record between two maxima if such a process were the controlling factor.

The record of subaerial extrusive volcanism in the circum-Pacific region has been summarized by McBirney et al. (1974) for Oregon and Central America, 


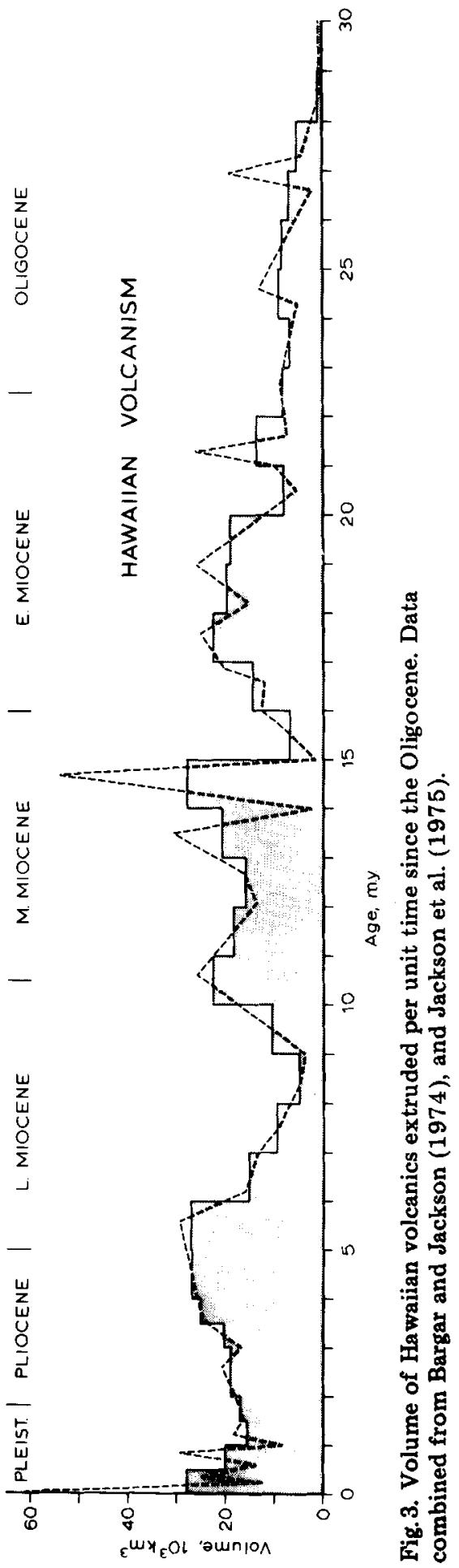


and by Kennett et al. (1977) for the southwestern Pacific, Central America, and North America. They report a strong maximum in volcanic activity about 14-16 m.y. ago and another beginning 1 or 2 m.y. ago with lesser maxima at about 4-6 and 8-11 m.y. ago. These four maxima correlate with times of increased ash accumulation in deep-sea sediments (Kennett et al., 1977; Hein et al., 1978).

Scheidegger and Kulm (1975) describe the major element chemistry of 25 ash layers ranging in age up to 7.75 m.y. recovered at DSDP Site 178 in Gulf of Alaska off the Alaska Peninsula. They found that the $\mathrm{SiO}_{2}$ content of the ash varies with age, having maxima at $0,2.5$, and $5 \mathrm{~m} . \mathrm{y}$ ago, and minima at about 1.25 and 3.5 m.y. ago. Subsequent work by Scheidegger et al. (1977) provides additional data which further substantiate the general increase in silica content of ash layers derived from other North Pacific volcanic arcs (Kamchatka and Central Aleutian) during the past 1.5 m.y. In addition, Hein et al. (1978) note how maxima in ash-layer accumulation north of the Aleutian Arc coincide well with maxima in $\mathrm{SiO}_{2}$ content of ash layers derived from the Alaska Peninsula. Scheidegger and Kulm (1975) and Scheidegger et al. (1977), suggest that the changing chemistry of the volcanic ash may be controlled by changes in subduction rates along the North Pacific volcanic arcs. Their work implies that not only the generation but also the evolution of calc-alkaline magmas may be influenced by changes in subduction rates.

The best data set pertaining to volumetric extrusion rates with time in a mid-plate setting is that of Jackson, Shaw and Bargar on the history of Hawaiian Ridge volcanism. Combining the results of Bargar and Jackson (1974) who calculated volumes of all the shield volcanoes along the HawaiiEmperor chain, and Jackson et al. (1975) who presented ages of all the volcanoes, a plot of volcanic extrusion volume vs. time can be created. Fig. 3 shows this plot of the age and volume of the Hawaiian volcanoes (connected by dashed lines) and the average volume extruded per unit time (shaded area).

Fig. 4 presents all of this information, Hawaiian extrusion, DSDP site 178 ash-layer silica variations (both averaged over $0.5-$ or $1.0-\mathrm{m} . \mathrm{y}$. intervals which assumes the processes are continuous), deep-sea ash-layer accumulation, circum-Pacific volcanic episodes, and spreading rates from the EPR and Juan de Fuca Ridge. When all these data are examined together temporal correlations become apparent; processes of rise-crest magmatism, mid-plate volcanism and subduction-zone volcanism show similar variations. All factors plotted in Fig.4 show simultaneous increases during the past $1.5 \mathrm{~m} . \mathrm{y}$. Another maximum in the values pertaining to extrusive volcanism apparently occurred about $5 \mathrm{~m} . \mathrm{y}$. ago, and spreading rates increase from about 1.3 to at least 2.4 and possibly $3.8 \mathrm{~m} . \mathrm{y}$. ago. Increased extrusion rates in both Hawaii and the Oregon Cascades correspond to times of more rapid sea-floor spreading along the various Pacific ridges al though spreading rate changes are about $10 \%$ of their average value while the extrusion rates vary by over $50 \%$. Taken together the data presented here, lends support to Kennett and Thunell's (1975) suggestion that small changes in spreading rates are magnified in volcanic discharge 

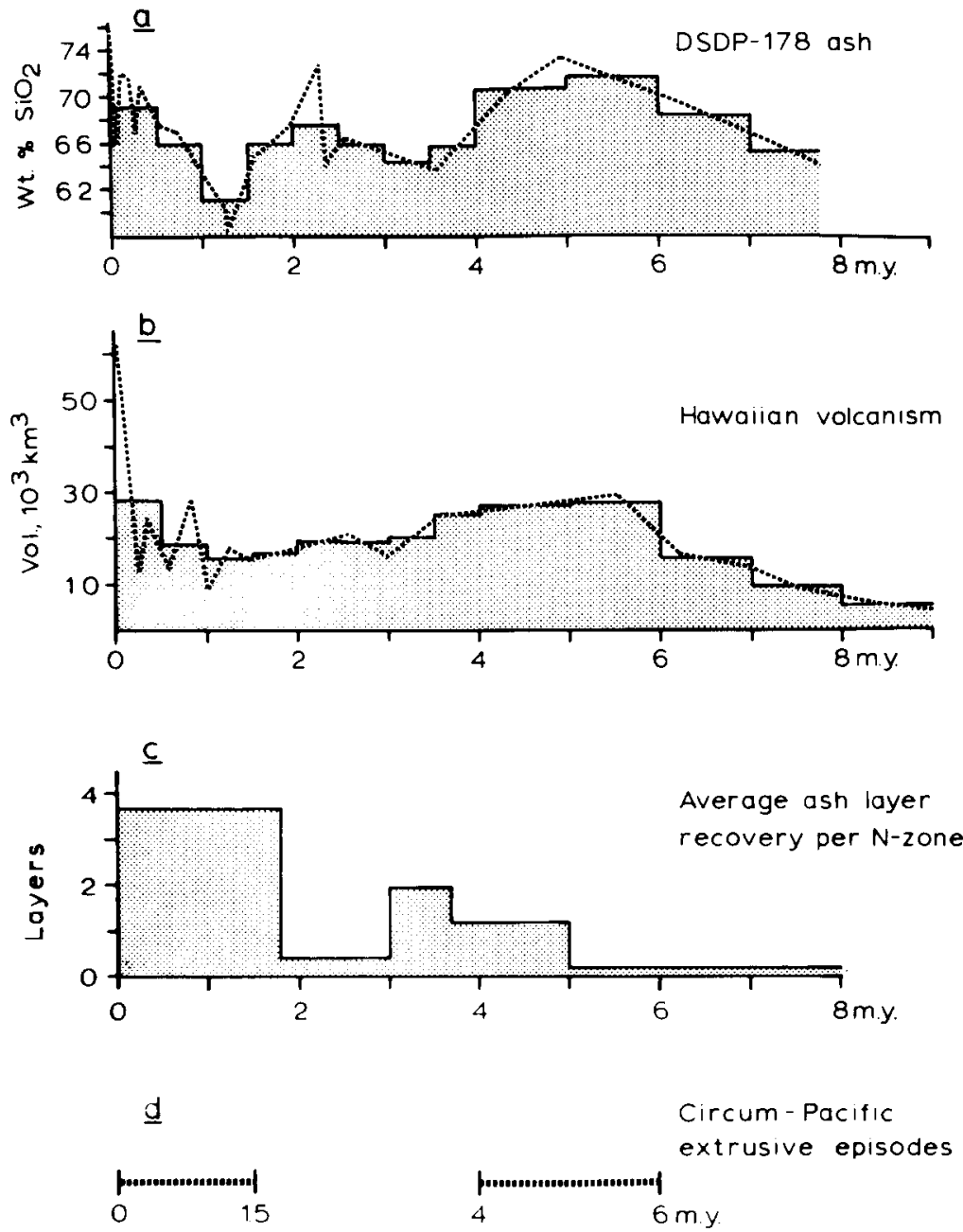

$\underline{e}$

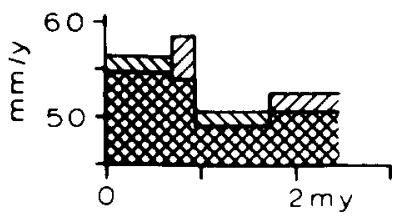

Jde $F$ spreading Time scales

MIII Tarling + Mitchell

QDD klitgord

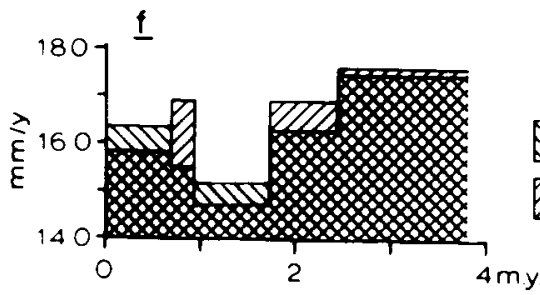

EPR spreading Time scales

DIVIV Tarling - Mitchell

DDA kitgord 
rates and tend to confirm "the possibility of Pacific-wide synchronization of magmatic episodes both in the center of the plate and at its margins" suggested by Jackson and Shaw (1975, p. 1874) from an analysis of a different type of data.

\section{Possible links between spreading and extrusion processes}

The relation between horizontal plate motion and melting rates, assumed to be reflected in extrusion rates, is probably the changing amount of shearing at the lithosphere boundary (Shaw, 1973; Shaw and Jackson, 1973). Shaw (1973) has postulated that increased shear in the upper asthenosphere may correspond to periods of increased melting along the Hawaiian Ridge trend. In subduction zones, shearing along the upper surface of the slab apparently results in increased temperatures in that region (Minear and Toksoz, 1970; Turcotte and Shubert, 1973) and may play an important role in the partial melting of the slab (Wyllie, 1973). For material close to its melting temperature, a slight increase in the amount of shearing might trigger appreciable magma generation. A second important variable in subduction-zone magma generation is the amount of water present (McBirney, 1969; Boettcher, 1973; Nicholls and Ringwood, 1973; Kushiro, 1973). Water is delivered to the melting site in the form of hydrous minerals in the upper lithosphere and possibly by entrapment in sediments carried into the subduction zone. The $\mathrm{SiO}_{2}$ content of the magma may depend on the amount of water present in the zone of magma generation (Boettcher, 1973). If subduction rates increase, more volatiles may be brought into the zone of magma generation, resulting in the formation of a more siliceous magma (Sugimura and Uyeda, 1973; Sugisaki, 1976).

These relationships tie together the various processes documented in Fig. 4 . Increased total spreading rates record greater horizontal plate velocities. This increase apparently results in increased shear and melting in the lithosphereasthenosphere boundary region (Shaw, 1973) which in turn is reflected in the greater volumes of Hawaiian extrusive rocks (Figs. 3 and $4 \mathrm{~b}$ ). Within the subduction zone, increased subduction rates probably result in increased shear heating along the top of the slab and an increased supply of water to the melting zone (Sigimura and Uyeda, 1973). The observed changes in extrusion volumes (Fig.3) and $\mathrm{SiO}_{2}$ content of volcanic ash (Fig.4a) may reflect these changes in the melting process.

In view of this apparent relationship between spreading rate and mid-plate and convergent-boundary volcanism, Fig. 3 forms the basis for some interesting speculations. Hawaiian extrusion rates were at a minimum during the Middle Oligocene, and occurred in definite pulses during the Early and Middle

Fig.4. Temporal variations in pan-Pacific volcanic processes. (a) $\mathrm{SiO}_{2}$ content of Aleutian ash layers. (b) Extrusion of Hawaiian volcanics, (c) Average ash-layer accumulation per $\mathrm{N}$-zone (after Kennett et al., 1977). (d) Extrusive episodes in the circum-Pacific area. (e) Juan de Fuca Ridge spreading rates. (f) East Pacific Rise spreading rates. 
Miocene, at the Miocene Pliocene boundary, and at present. This pattern of volcanism corresponds well with the pattern of maxima reported by Kennett et al. (1977) and with the general increase in Pacific-border tectonism that occurred near the Paleogene-Neogene boundary about 20-25 m.y. ago and documented by Dott (1969). At the same time as this increase in Pacific-border tectonism the rate of rotation of the Pacific plate about the Hawaiian pole apparently increased by a factor of approximately three (Clague and Jarrard, 1973; Van Andel et al., 1975). The volcanic pattern observed along the Hawaiian Ridge (Fig.3) appears to match circum-Pacific events reasonably well. If Shaw's (1973) suggestion, supported by Fig.4, is correct and times of greater extrusion in Hawaii record times of increased spreading rates then it is possible that the circum-Pacific Neogene volcano-tectonic events documented above and by Dott (1969) may also be related to periods of more rapid seafloor spreading.

\section{SUMMARY}

The best location for the determination of Plio-Pleistocene variations in spreading rate is along the Nazca-Pacific plate boundary where spreading rates are at a maximum and topographic noise is low. Combined data from four axial survey areas along this part of the EPR reveal that: (1) the angular velocity of opening over the last $1.73 \mathrm{~m} . \mathrm{y}$. is $1.475^{\circ} / \mathrm{m}$.y. and the predicted increase in linear spreading velocities towards the equator of plate rotation occurs in a general sense; and (2) spreading rates are not uniform with time but rather decrease from least 2.4 to $1.3 \mathrm{~m} . \mathrm{y}$. ago and then increase to the present (Tables 1 and 2). All four survey areas show a reduced spreading velocity during the Jaramillo to Olduvai time interval, $0.92-1.73$ m.y. ago. This same pattern of slower rates about $1.3 \mathrm{~m} . y$. ago may also occur across the Juan de Fuca Ridge in the northeastern Pacific (Table 3).

An investigation of the history of other volcanic processes in the Pacific region, both subduction-zone related and mid-plate, reveal maxima and minima that occur at the same time as the spreading rate high $0-0.92 \mathrm{~m} . \mathrm{y}$. ago and low 0.92-1.73 m.y. ago (Fig.4). These maxima in extrusion rates in Hawaii and the circum-Pacific regions, in deep-sea ash-layer frequency, and in $\mathrm{SiO}_{2}$ content of Aleutian ash layers all appear to occur at the same 5-m.y. intervals observed by Kennett et al. (1977) and imply the existence of spreading rate variations of the same frequency.

\section{ACKNOWLEDGEMENTS}

We thank Vern Kulm for reviewing this manuscript. This report has benefited from discussions with Will Schweller. E.D. Jackson kindly advised us of some pertinent references. This work has been supported by the National Science Foundation via the IDOE Nazca Plate Project, grants GX-28675 and OCE 76-05903 to Rea and in part by NSF grant OCE 76-98545 to Scheidegger. 


\section{REFERENCES}

Bargar, K.E. and Jackson, E.D., 1974. Calculated volumes of individual shield volcanoes along the Hawaiian-Emperor chain. U.S. Geol. Surv., J. Res., 2: 545-550.

Berg, E. and Sutton, G.H., 1974. Dynamic interaction of seismic and volcanic activity of the Nazca plate edges. Phys. Earth Planet. Inter., 9: 175-182.

Boettcher, A.L., 1973. Volcanism and orogenic belts - the origin of andesites. Tectonophysics, 17: 223-240.

Chase, C.G., 1972. The N plate problem of plate tectonics. Geophys. J. R. Astron. Soc., 29: 117-122.

Clague, D.A. and Jarrard, R.D., 1973. Tertiary Pacific plate motion deduced from the Hawaiian-Emperor chain. Geol. Soc. Am. Bull., 84: 1135-1154.

Cox, A, 1969. Geomagnetic reversals. Science, 163: 237-245.

Dott, R.H., Jr., 1969. Circum-Pacific Late Cenozoic structural rejuvenation: implications for sea floor spreading. Science, 166: 874-876.

Hays, J.D. and Ninkovich, D., 1970. North Pacific deep-sea ash chronology and age of present Aleutian underthrusting. In: J.D. Hays (Editor), Geological Investigations of the North Pacific. Geol. Soc. Am. Mem., 126: 263-290.

Hein, J.R., Scholl, D.W. and Miller, J., 1978. Episodes of Aleutian Ridge explosive volcanism. Science, 199: 137-141.

Herron, E.M., 1972. Sea-floor spreading and the Cenozoic history of the east-central Pacific. Geol. Soc. Am. Bull., 83: 1671-1692.

Jackson, E.D. and Shaw, H.R., 1975. Stress fields in central portions of the Pacific plate: delineated in time by linear volcanic chains. J. Geophys. Res., 80: 1861-1874.

Jackson, E.D., Shaw, H.R. and Bargar, K.E., 1975. Calculated geochronology and stress field orientations along the Hawaiian chain. Earth Planet. Sci. Lett., 26: 145-155.

Kennett, J.P. and Thunell, R.C., 1975. Global increase in Quaternary explosive volcanism. Science, 187: 497-503.

Kennett, J.P., McBirney, A.R. and Thunell, R.C., 1977. Episodes of Cenozoic volcanism in the circum-Pacific region. J. Volcanol. Geotherm. Res., 2: 145-163.

Klitgord, K.D., 1974. Near-bottom geophysical surveys and their implications on the crustal generation process, sea-floor spreading history of the Pacific, and the geomagnetic time scale: 0 to $6 \mathrm{~m} . y$. B.P. Ph.D. Thesis, University of California, San Diego, Calif., $177 \mathrm{pp}$.

Kushiro, I., 1973. Origin of some magmas in oceanic and circum-oceanic regions. Tectonophysics, 17: 211-222.

LaBrecque, J.L., Kent, D.V. and Cande, S.C., 1977. Revised magnetic polarity time scale for Late Cretaceous and Cenozoic time. Geology, 5: 330-335.

McBirney, A.R., 1969. Compositional variations in calc-alkaline suites of Central America. In: Proceedings of the Andesite Conference. Oreg., Dep. Geol. Miner. Ind., Bull., 65: 185-189.

McBirney, A.R., Sutter, J.F., Naslund, H.R., Sutton, K.G. and White, C.N., 1974. Episodic volcanism in the central Oregon Cascade range. Geology, 2: 585-589.

Minear, J.W. and Toksoz, M.N., 1970. Thermal regime of a downgoing slab and new global tectonics. J. Geophys. Res., 75: 1397-1419.

Minster, J.B., Jordan, T.H., Molnar, P. and Haines, E., 1974. Numerical modelling of instantaneous plate tectonics. Geophys. J. R. Astron. Soc., 36: 541-576.

Mogi, L., 1974. Active periods in the world's chief seismic belts. Tectonophysics, 22 : 265-282.

Morgan, W.J., 1968. Rises, trenches, great faults, and crustal blocks. J. Geophys. Res., 73 : 1959-1982.

Nicholls, I.A. and Ringwood, A.E., 1973. Effect of water on olivine stability in tholeiites and the production of silica-saturated magmas in the island-arc environment. J. Geol., 81: 285-300. 
Ninkovich, D. and Donn, W.L., 1976. Explosive Cenozoic volcanism and climatic implications. Science, 194: 899-906.

Noble, D.C., Mckee, E.H., Farrar, E. and Petersen, U., 1974. Episodic Cenozoic volcanism and tectonism in the Andes of Peru. Earth Planet. Sci. Lett., 21: 213-220.

Rea, D.K., 1975. Tectonics of the East Pacific Rise, $5^{\circ}$ to $12^{\circ} \mathrm{S}$. Ph.D. Thesis, Oregon State University, Corvallis, Oreg., $139 \mathrm{pp}$.

Rea, D.K., 1976a. Changes in the axial configuration of the East Pacific Rise near $6^{\circ} \mathrm{S}$ during the past 2 m.y. J. Geophys. Res., 81: 1495-1504.

Rea, D. K., $1976 \mathrm{~b}$. Analysis of a fast-spreading rise crest: the East Pacific Rise, $9^{\circ}$ to $12^{\circ}$ South. Mar. Geophys. Res., 2: 291-313.

Rea, D.K., 1977. Local axial migration and spreading rate variations, East Pacific Rise, $31^{\circ}$ S. Earth Planet. Sci. Lett., 34: 78-84.

Rea, D.K., 1978. Asymmetric sea-floor spreading and a non-transform axis offset: the East Pacific Rise $20^{\circ} \mathrm{S}$ survey area. Geol. Soc. Am. Bull., 89: 836-844.

Rea, D.K. and Blakely, R.J., 1975. Short-wavelength magnetic anomalies in a region of rapid seafloor spreading. Nature, 255: 126-128.

Scheidegger, K.F. and Kulm, L.D., 1975. Late Cenozoic volcanism in the Aleutian Arc: information from ash layers in the northeastern Gulf of Alaska. Geol. Soc. Am. Bull., 86: $1407-1412$.

Scheidegger, K.F., Corliss, J.B., Jezek, P.A. and Ninkovich, D., 1977. Ash-layer record of explosive volcanic eruptions of the Aleutian and Kamchatkan volcanic arcs. Trans. Am. Geophys. Union (EOS), 58: 1248.

Shaw, H.R., 1973. Mantle convection and volcanic periodicity in the Pacific: evidence from Hawaii. Geol. Soc. Am. Bull., 84: 1505-1526.

Shaw, H.R. and Jackson, E.D., 1973. Linear island chains in the Pacific: result of thermal plumes or gravitational anchors? J. Geophys. Res., 78: 8634-8652.

Stewart, R.J., 1975. Late Cainozoic explosive eruptions in the Aleutian and Kuril Island Arcs. Nature, 258: 505-507.

Sugimura, A. and Uyeda, S., 1973. Island Arcs, Japan and its Environments. Elsevier, Amsterdam, $247 \mathrm{pp}$.

Sugisaki, R., 1976. Chemical characteristics of volcanic rocks: relation to plate movements. Lithos, 9: 17-30.

Tarling, D.H. and Mitchell, J.G., 1976. Revised Cenozoic polarity time scale. Geology, 4: $133-136$.

Turcotte, D.L. and Schubert, G., 1973. Frictional heating of the descending lithosphere. J. Geophys. Res., 78: 5876-5886.

Van Andel, Tj. H., Heath, G.R. and Moore, T.C., Jr., 1975. Cenozoic History and Paleoceanography of the Central Equatorial Pacific Ocean. Geol. Soc. Am., Mem., 143: 134 pp.

Vogt, P.R., 1972. Evidence for global synchronism in mantle plume convection and possible significance for geology. Nature, 240: $338-342$.

Wyllie, P.J., 1973. Experimental petrology and global tectonics - a preview. Tectonophysics, 17: 189-209. 